\title{
Esboço de Auto-Análise.
}

Pierre Bourdieu. Tradução, introdução, cronologia e notas - Sergio Miceli. São Paulo: Companhia das Letras, 2005. 140 p. ISBN: 85-359-0655-X.

\section{Resenha por Alexandre Reis Rosa (EAESP/FGV)}

A opção de ser intelectual remete o indivíduo a uma condição que o distingue de outros profissionais. Tal distinção se dá pela incapacidade de se separar a vida da obra. Isto é, a atividade intelectual não tem hora nem lugar marcado, tampouco depende de uma organização ou de uma mesa de trabalho. A reflexão acerca da realidade é um trabalho constante e tende a se misturar com o papel do intelectual no mundo social em que ele vive. Dessa forma, as biografias tendem a dizer muito sobre a trajetória de uma pessoa; mas, quando se trata de um pensador, diz muito também sobre o seu projeto intelectual.

Esse é o caso do presente livro. Embora declarado pelo próprio Bourdieu, que o conteúdo exposto não trata de uma autobiografia, é flagrante que a narrativa ganha esta conotação na medida em que se baseia nos principais momentos de sua trajetória como homem e intelectual que foi. A proposta teórica de Bourdieu neste trabalho é aplicar em si mesmo o método reflexivo - que é uma marca de suas pesquisas - e com isso escrever um livro "para desencorajar as biografias e os biógrafos, como que revelando, por uma espécie de ponto de honra profissional, as informações que [ele] teria gostado de encontrar, quando tentava compreender os escritores ou os artistas do passado" (p. 133).

O livro está divido em três partes. A primeira é uma introdução elaborada por Sérgio Miceli - um dos principais divulgadores de Bourdieu no Brasil - que busca situar o leitor no contex to do livro e principalmente nas razões por detrás da sua elaboração. Além de um panorama da obra, Miceli chama atenção para as sobreposições entre os deslocamentos pessoais e os deslocamentos teóricos de Bourdieu. Assim, o leitor já adentra o texto com essa pré-condição de enxergar, nas entrelinhas, as pistas do monumento teórico do autor.

Na segunda parte temos o que Bourdieu vai denominar de "esboço de autoanalise" preparado ao longo de muitos anos de reflexão, que só na véspera de sua morte foram sistematizados neste livro. Os núcleos da narrativa refletem o percurso do autor no espaço social em que viveu e ao mesmo tempo revelam a incompatibilidade prática entre os mundos sociais que tal percurso conecta sem de fato reconciliá-los. Deste modo, Bourdieu segue uma linha não cronológica em sua narrativa, pois para ele "compreender [a narrativa] é primeiro compreender 
o campo com o qual e contra o qual cada um se fez" (p. 40). Assim, as primeiras páginas sintetizam a dinâmica do campo acadêmico a partir dos anos 50, quando ingressa na Escola Normal Superior e passa a conviver com figuras ilustres da filosofia francesa, cujas posições serão duramente contestadas pelo autor que, de partida, já identifica que os agentes do campo compartilham um habitus diferente do seu. A altivez e o distanciamento do mundo social adotado pelos filósofos é o grande estopim do seu afastamento, que é confirmado na Argélia, quando, após formar-se, o autor é convocado para o exército francês e extrai dessa experiência a sua primeira pesquisa etnológica, cujas marcas foram determinantes na sua postura intelectual e na opção pelo campo sociológico.

Outras duas passagens descritas pelo autor são a experiência no internato, durante sua humilde infância no interior da França, e a consagração como titular da cadeira de sociologia no tradicional Collège de France. $\mathrm{O}$ antagonismo destes dois momentos foi o grande fantasma na vida de Bourdieu. Foram responsáveis pelo que ele denomina de habitus clivado, que é o produto de uma conciliação dos contrários que o levaram a viver noites de insônia, quando preparava sua aula inaugural que, para ele, foi um concentrado de todas as suas contradições. Um sentimento de ser perfeitamente indigno em virtude das suas origens e ao mesmo tempo merecedor em virtude da sua impecável trajetória intelectual. Com efeito, ele elabora uma "aula sobre a aula" e dispara sua crítica para uma platéia composta por Lévi-Strauss, Dumézil, Foucault etc. Entretanto, percebe, já na consumação do ato, que o que para ele era "uma solução psicológica constituía um desafio à ordem simbólica, um ataque à dignidade da instituição" (p. 131). Assim, Bourdieu encerra a segunda parte do livro, descrevendo o mal-estar daquele episódio, cujo sentimento foi mais de gafe do que de transgressão. Finalmente, a terceira parte do livro traz uma cronologia bastante detalhada da vida e da obra de Bourdieu. Exibe as datas e locais que marcaram sua trajetória como um guia para que o leitor se situe no texto, uma vez que a narrativa não segue um padrão linear.

Embora o conteúdo do livro se ocupe mais da obra do que da vida do autor, é possível identificar algumas lacunas nessa descrição. Um exemplo disso é a pouca ênfase do autor na origem de dois dos seus conceitos centrais: o de habitus e o de campo. Mesmo sinalizando, timidamente, a experiência na Escola Normal e a pesquisa na Argélia como possíveis fontes, o leitor se frustra pela falta de precisão nestes espaços. Os embates e a postura subversiva de Bourdieu junto ao statu quo da filosofia francesa dão uma conotação muito mais política do que epistemológica ao texto, contribuindo pouco para uma reflexão sobre o autor em relação à sua própria obra. Por outro lado, esse viés político é excelente oportunidade para se compreender o componente simbólico presente nas relações de poder que marcam os diferentes mundos sociais descritos por ele. 
Para o campo da Administração, em particular o de estudos organizacionais, o presente livro tem dupla utilidade: para os que ainda estão começando, o livro ajuda a contextualizar e a dar uma sequiência mais ou menos lógica da obra de Bourdieu, o que pode ser muito útil na hora de uma revisão bibliográfica. Para os que já conhecem o autor e agora buscam as interfaces com outros autores, o livro ajuda na medida em que o próprio Bourdieu esclarece sua relação com o estruturalismo e o pós-modernismo e com autores como Foucault, por exemplo, que tem grande entrada nos estudos organizacionais. Em linhas gerais, a leitura desse esboço de auto-análise constitui uma oportunidade de o leitor olhar o mundo que Pierre Bourdieu viveu a partir das lentes que ele mesmo construiu e assim perceber que a vida intelectual acontece, reflexivamente, dentro da vida social. 